\title{
Impact of energetics development on the sustainability of the regional economy
}

\author{
Elena Merkulova ${ }^{1}$, Oleg Kondrakov ${ }^{2}$, Vera Menshchikova ${ }^{1}$, and Yulia Vertakova $^{3, *}$ \\ ${ }^{1}$ Tambov State Technical University, 392000, 106, Sovetskaya Str., Tambov, Russia \\ ${ }^{2}$ Derzhavin Tambov State University, 392000, 33, Internatsionalnaya Str., Tambov, Russia \\ ${ }^{3}$ Southwest State University, 305004, 94, 50 Let Oktyabrya Str., Kursk, Russia
}

\begin{abstract}
Gross regional product (GRP) per capita is the main indicator of the development level in a region, determining budgetary economic security and living standards of the population in the region. The energy sector has a great influence on the economic and sustainable development of the regions. The studying problem of the influence level in electricity consumption, the electrical equipment of labour, the volume of industry shipped products on the level of GRP is relevant. The main indicator of ensuring economic security in the region is a high level of GRP per capita. The factors affecting this indicator are revealed. The paper considers the degree of GRP dependence on the following indicators: electricity consumption in industry, the volume of goods shipped by manufacturing industries, the electrical equipment in industrial work (manufacturing industries). By the method of factor analysis, generalized characteristics of regional development are made.
\end{abstract}

\section{Introduction}

Sustainable economic development of the regions is impossible without a balanced, reliable energy supply. Electric energy is used in almost all technological processes: drives various mechanisms; used in technological installations for heating products, welding, melting metals, electrolysis, for producing plasma, for cleaning materials and gases, for obtaining new materials using electrochemistry, for obtaining mechanical energy, for carrying out mechanical and physical processes of processing materials, crushing, mixing, filtering, grinding, centrifuging, drying, conducting electrochemical reactions, the use of electrostatic phenomena (electrocracking, deposition of dusts and mists). Energy is required for the transport of raw materials and finished commodity. Electricity is the only form of energy for artificial lighting. The growing scale of modern industrial enterprises causes an increasing need for all forms of energy. Important indicators for the regions are: GRP per capita, the amount of electrical energy consumption and the electrical equipment of workers, showing how much electricity consumed a year per worker. Today, Russia is inferior to the leading world economically developed countries (USA, France, Germany) in terms of per-capita consumption of electrical energy, as well as in the level of electrical

\footnotetext{
* Corresponding author: vertakova7@ya.ru
} 
equipment in industrial work. In comparison with the developed countries, in Russia the efficiency of using electric energy is noticeably less. To identify the factors influencing the fuel and energy complex (FEC) on the development of production and economic growth, we trace the following chain: electricity consumption in industry - electrical equipment of labour - volume of goods shipped by manufacturing industry - GRP per capita.

Theoretical issues of the energy study as a basic sector of the economy are discussed in the works of L. Matraeva [1], L. Proskuryakova [2], T. Miroshnikova [3], T. Meshcheryakova [4]. In these works, the state and sustainable development prospects of the energy complex were considered.

The greatest contribution to the formation of the theoretical, methodological and methodological provisions of Russian energy security and its subjects was made by $\mathrm{V}$. Milov [5], M.F. Keating [6], A. Mottaeva [7], I. Bashmakov [8], A. Gorshkov [9], S.N. Bobylev [10], A.I. Tatarkin [11], Y. Vertakova [12]. They developed methods for diagnosing energy security based on an indicative analysis taking into account the influence of various factors, and conducted research on the reliability of energy systems. These authors have contributed to the diagnosis of the energy complex from the standpoint of economic security. However, development aspects of the fuel and energy complex as a basic element of all economic activity types, forming the level of economic development in the region, while experiencing the impact of the economic crisis, remain little studied. Interrelationships aspects of GRP per capita, the consumption of electric energy in industry, the electrical equipment of labour, the volume of goods shipped are not sufficiently well developed. These indicators are important from the standpoint of ensuring energy and economic security, especially in the current economic conditions of Russia, due to the impact of sanctions.

The electric power industry, along with other sectors of the national economy, is considered as part of a single national economic system. It determines the development level of all economy sectors, quality of life and economic growth of the regions.

\section{Materials and Methods}

The work develops a hypothesis about the relationship of indicators: GRP per capita, electricity consumption by industry, the electrical equipment of an employee, the volume of goods shipped by manufacturing industries, which characterize the sustainable development of the regions. The growth of GRP depends on the development pace of industrial production, which is unthinkable without the main resource base - electrical energy. The more electricity is consumed in the industry, the more goods are produced and services are provided. The study used Microsoft Excel and IBMSPSS Statistica application software, which increased the accuracy of the calculations. The study made it possible for the first time to generalize part of the empirical data on the prospects for the economic development of regions based on reliable energy supply.

The objectives of this study: 1) Assessment of the development impact of industry on the size of the regional GRP, which determines the economic development level of the regions. 2) Determination of the relationship between the consumption of electrical energy and the electrical equipment of labor in industry. 3) Grouping of regions in accordance with the level of the identified generalizing characteristics significance. The calculations were carried out on the basis of Rosstat data.

\section{Results}


The main indicator of economic security ensuring of the region is a high level of GRP per capita. To identify the factors affecting this indicator, consider the degree of its dependence on the following indicators: electricity consumption in industry, the volume of goods shipped by manufacturing industries, the electrical equipment in industrial work (manufacturing industries). The method of factor analysis allows to identify generalizing characteristics of regional development.

Investigating the scree chart, showing the dependence of eigenvalues on components, we notice a sharp decline in components starting from the second value. Thus, analyzing the data using the principal component method, we extract two components (Table 1). The resulting components are equivalent. There is no pronounced factor in the data.

Table 1. The matrix of the main components

\begin{tabular}{|c|c|c|}
\hline \multirow[t]{2}{*}{ Readings } & \multicolumn{2}{|c|}{ Component } \\
\hline & 1 & 2 \\
\hline GRP per capita & 0.374 & 0.537 \\
\hline Electricity consumption in industry & 0.863 & -0.083 \\
\hline Volume of goods shipped to manufacturing industries & 0.649 & 0.357 \\
\hline Electrical equipment labour of manufacturing industries & 0.452 & -0.798 \\
\hline
\end{tabular}

To simplify the interpretation of factors and minimize the number of variables, the Varimax orthogonal rotation method was used. The rotated matrix of components presented in table 2 shows the real structure of the interrelations studied. The Varimax rotation with Kaiser normalization converged in three iterations.

Table 2. Rotated matrix of the main components

\begin{tabular}{|l|c|c|}
\hline \multirow{2}{*}{} & \multicolumn{2}{|c|}{ Component } \\
\cline { 2 - 3 } & $\mathbf{1}$ & $\mathbf{2}$ \\
\hline GRP per capita & 0.618 & -0.216 \\
\hline Electricity consumption in industry & 0.651 & 0.572 \\
\hline Volume of goods shipped to manufacturing industries & 0.735 & 0.091 \\
\hline Electrical equipment labour of manufacturing industries & -0.101 & 0.912 \\
\hline
\end{tabular}

The first component revealed the interrelationship of GRP per capita and the volume of goods shipped by manufacturing industries. The second component is the consumption of electricity in industry and the electrical equipment of labour in industry.

The evaluation of the economic development of the regions of the Russian Federation according to the studied indicators will be considered using the definition of descriptive indicators of statistics and the construction of clusters using the Ward method. The result of the hierarchical classification of the source data allowed us to identify four groups of regions that are similar in certain characteristics (Table 3).

Based on the calculations, 21 regions were in the first group - regions with developed economies. In most regions belonging to the first group, the most favourable situation is observed by the studied indicators: GRP per capita 427348.40 roubles - $(8 \%$ below the national average); electricity consumption in industry 15136.600 million $\mathrm{kW}$ per hour (2 times higher than the average in the Russian Federation); electric power of labour in industry $108202.1905 \mathrm{kWh}$ per person. (1.8 times higher than the average in the Russian Federation); volume of goods shipped by manufacturing industries 863195.4286 million roubles ( 2 times higher than the average in the Russian Federation). The second group (industrial regions) is the most numerous in composition (59 regions) and geographically scattered. Here are the regions with average and low values of the studied indicators. GRP per capita 328609.58 rub (1.4 times lower than the average in the Russian Federation); electricity consumption in industry 2324.8746 million $\mathrm{kWh}$ (3 times lower than in the 
Russian Federation); electric power of labour in industry $24294.1356 \mathrm{kWh}$ per person (2.5 times lower than in the Russian Federation); volume of goods shipped by manufacturing industries 18610.2203 million roubles (2.2 times lower than the average in the Russian Federation).

Table 3. Typology of the regions according to the socio-economic and energy indicators by regions of the Russian Federation

\begin{tabular}{|c|c|}
\hline Type & Regions \\
\hline $\begin{array}{l}\text { high- } \\
\text { developed }\end{array}$ & $\begin{array}{l}\text { Belgorod, Lipetsk, Moscow, Vologda, Volgograd, Leningrad, Murmansk, Nizhny } \\
\text { Novgorod, Orenburg, Samara, Sverdlovsk, Chelyabinsk, Kemerovo, Irkutsk regions. } \\
\text { Republics: Komi, Karelia, Bashkortostan, Tatarstan. Krasnoyarsk Territory, Perm } \\
\text { Territory, St. Petersburg. }\end{array}$ \\
\hline industrial & $\begin{array}{l}\text { Bryansk, Vladimir, Voronezh, Ivanovo, Kaluga, Kostroma, Kursk, Oryol, Ryazan, } \\
\text { Smolensk, Tambov, Tver, Tula, Yaroslavl, Arkhangelsk, Arkhangelsk without Nenets } \\
\text { auton. districts, Kaliningrad, Novgorod, Pskov, Astrakhan, Rostov, Kirov, Penza, } \\
\text { Saratov, Ulyanovsk, Kurgan, Tyumen (without Khanty-Mansi Autonomous Area), } \\
\text { Novosibirsk, Omsk, Tomsk, Amur, Magadan, Sakhalin regions. Republics: Adygea, } \\
\text { Kalmykia, Crimea, Dagestan, Ingushetia, Kabardino-Balkaria, Karachay-Cherkessia, } \\
\text { North Ossetia (Alania), Chechen, Mari El, Mordovia, Udmurt, Chuvash, Altai, } \\
\text { Buryatia, Tyva, Sakha (Yakutia). Krasnodar Territory, Stavropol Territory, Altai } \\
\text { Territory, Trans-Baikal Territory, Primorye Territory, Kamchatka Territory, } \\
\text { Khabarovsk Territory. Jewish Auth. region, Chukotka Autonomous Region, } \\
\text { Sevastopol }\end{array}$ \\
\hline $\begin{array}{l}\text { donor } \\
\text { regions }\end{array}$ & $\begin{array}{l}\text { Moscow, Yamalo-Nenets autonomous area, Khanty-Mansiysk aut. District, Nenets } \\
\text { Autonomous Okrug }\end{array}$ \\
\hline $\begin{array}{l}\text { energy } \\
\text { facilitated }\end{array}$ & The Republic of Khakassia \\
\hline
\end{tabular}

The third group consisted of donor regions. Three of the four indicators studied in the regions of this group significantly exceed the national average: GRP per capita of 2899186.73 roubles -6 times; electricity consumption in the industry 22491.7750 million $\mathrm{kWh}-3.4$ times; volume of goods shipped by manufacturing industries 1471660.2500 million roubles -3.6 times. And only the electrical equipment of labour in industry in the donor regions is $32523.0250 \mathrm{kWh}$ per person - 2 times lower than the average in the Russian Federation.

The Republic of Khakassia was singled out as a separate group due to the maximum value of the electric power index in Russia: $1364405.0000 \mathrm{kWh}$ per person. At the same time, other indicators are significantly lower than the national average. Based on the study, the following information was obtained. The development of industrial production in the regions is accompanied by a high indicator of the volume of goods shipped. This situation is observed in Moscow, Moscow Region, Sverdlovsk Region, the Republic of Tatarstan, St. Petersburg, and Lipetsk Region. Here there are large enterprises of mechanical engineering, non-ferrous and ferrous metallurgy, chemical and petrochemical industries. In the regions of Yamalo-Nenets Autonomous Okrug, Khanty-Mansi Autonomous Okrug - Yugra, Chukotka Autonomous Okrug, Tyumen Oblast GRP is formed due to mining.

Electric equipment ratio depends on the consumption level of electrical energy. On the other hand, the use of energy-saving technologies is a deterrent. Climate conditions affect power consumption. The growth of industrial production is accompanied by an increase in the consumption of electrical energy in industry.

In some regions, there is a wealth of own energy resources and they are mainly oriented towards intraregional consumption (Moscow region, Chelyabinsk region, Kemerovo region, Voronezh region, Kursk region). In other regions there is an excess (Khanty-Mansi Autonomous Okrug, Tyumen Oblast, Krasnoyarsk Territory, Irkutsk Oblast, and 
Sverdlovsk Oblast), and they have the opportunity to sell energy resources to other regions. In such regions it is more preferable to develop energy-intensive production. The rest of the regions are deficient in their own energy sources, and they focus on tourism, agriculture or other economic activities (Bryansk region, the Republic of Ingushetia, the Jewish Autonomous Region, the Chechen Republic, the Republic of Kalmykia, the Republic of Tyva, the Altai Republic, the Adygea Republic, the Tambov Region, Krasnodar Territory, Republic of Adygea, Republic of Ingushetia).

Regions that have an excess of their own energy resources consume more electric energy (Khanty-Mansi Autonomous Okrug, Krasnoyarsk Territory, Irkutsk Region, Sverdlovsk Region, Tyumen Region, Moscow Region, Chelyabinsk Region, Kemerovo Region). Problem subsidized regions with low GRP have insignificant volumes of electricity consumption, low electrical power and, accordingly, low volume of industrial goods shipped (Chechen Republic, Republic of Tyva, Republic of Kabardino-Balkaria, Republic of Ingushetia, Republic of Karachay-Cherkessia).

The territorial placement equability of large electric-energy generating sources in the country is observed: hydroelectric power stations - Surgut, Bratsk, Sayano-Shushenskaya; thermal power plants - Zainsk (Republic of Tatarstan), Ryazan; nuclear power plants Kursk, Novovoronezh, Leningradskaya.

The application of the step-by-step method allowed revealing the most significant regression model:

$$
\mathrm{Y}=406142.320+15.197 \mathrm{x}_{1}-0,016 \mathrm{x}_{2}-0,417 \mathrm{x}_{2},
$$

where $\mathrm{Y}$ is the GRP per capita; $\mathrm{x}_{1}$ - electricity consumption in industry; $\mathrm{x}_{2}$ is the volume of goods shipped by manufacturing industries; $\mathrm{x}_{2}$ - electrical equipment of labor in industry (manufacturing).

For this model of dependence, the correlation index is $\mathrm{R}=0.53$, and the determination coefficient is $\mathrm{R} 2=0.45$, therefore, $45 \%$ of the variation of the effective indicator is due to the influence of factors included in the model, the corrected correlation index value was (0.673) with a standard error of estimation (3.097). The Durbin-Watson criterion was (1.38), therefore, the model will not be adequate for further calculations.

\section{Discussion}

Thus, the goal of the study to identify the relationship between the studied parameters was achieved. To solve the problem, factor analysis was used. Typological analysis of the regions revealed: four groups that differ in the level of socio-economic development; a high degree of divergence of the regions. The development laws of the Russian economy in a regional context are identified based on the indicators characterizing its spatial and temporal aspect.

\section{Conclusions}

Electric power is an important part of human life. The level of its development reflects the development degree of the productive society forces and the possibility of scientific and technological progress. Energy supply is a critical factor for the modern economy. Proper construction of a strategy for the production and use of energy resources in many ways predetermines the success of the strategy for economic growth in Russia. In this regard, the position of Russia is particular: the country has an "excessive" own energy potential, which has always been wasted irrationally, because there is a lot of it, and created disproportionate pressure on other economy sectors. As a result, the economy of many regions consumes too 
much energy and is overly dependent on the export of energy raw materials. Proper use of its own energy potential is the key to the economic policy success of any region. In the practice of the economic functioning of industrialized countries with objectively existing limited natural resources, the task of providing raw materials for production and livelihoods of the population has long been a matter of primary importance.

The energy system is interconnected with the economic and social aspects of regional development. All the problems arising in the fuel and energy complex (FEC) are not static, but are changing in dynamics due to the development of energy. In this connection, it is necessary to consider problems with the sustainable development of the fuel and energy complex from the point of view of an integrated approach, i.e. with all participants of the system of generation, transportation, distribution and consumption of electrical energy.

The implementation by the state of a policy aimed at the development of the domestic production base determines the preservation of existing and creation of new jobs, return of duties in the budget, stimulation of innovative development, orders for related industries and, as a result, socio-economic development of the territories and the country. As a result, a multiplicative socio-economic effect arises.

Thus, the implementation of the state industrial policy will create the prospects for the fixed assets development of the power industry and the conditions for ensuring reliable and sustainable development of the entire fuel and energy complex. The success of Russian economic growth depends on the proper construction of production, distribution, transfer and use of energy resources.

\section{References}

1. L. Matraeva, P. Solodukha, S. Erokhin, M. Babenko, Energy Policy, 125, 478-486 (2019) doi: 10.1016/j.enpol.2018.10.049

2. L. Proskuryakova, A. Kovalev, Applied Energy, 138, 450-459 (2015) doi: 10.1016/j.apenergy.2014.10.060

3. T. Miroshnikova, N. Taskaeva, Proceedings of the XV International Conference Topical Problems of Architecture, Civil Engineering, Energy Efficiency and Ecology, 73, (2016) doi: 10.1051/matecconf/20167307006

4. T. Meshcheryakova, International Science Conference SPBWOSCE Smart City, 106, (2016) doi: 10.1051/matecconf/201710606021

5. V. Milov, L. L. Coburn, I. Danchenko, Eurasian Geography and Economics, 47(3), 285-313 (2006) doi: 10.2747/1538-7216.47.3.285

6. M. F. Keating, C. Kuzemko, A.V. Belyi, A. Goldthau, Dynamics of Energy Governance in Europe and Russia, 1-19 (2012)

7. A. Mottaeva, Proceedings of the Conference on Energy Management of Municipal Transportation Facilities and Transport (EMMFT 2017), 90 (2017) doi: 10.1088/17551315/90/1/012124

8. I. Bashmakov, Energy Efficiency, 2(4), 369-386 (2009) doi: 10.1007/s12053-0099050-1

9. A. Gorshkov, V. Murgul, O. Oliynyk, Proceedings of the International Scientific Conference Week of Science in SPbPU - Civil Engineering (SPbWOSCE), 53 (2016) doi: 10.1051/matecconf/20165301045

10. S. N. Bobylev, O. V. Kudryavtseva, Y. Y. Yakovleva, Ekonomika Regiona-Economy of Region, 2, 148-159 (2015) doi: 10.17059/2015-2-12 
11. A. I. Tatarkin, Ekonomika Regiona-Economy of Region, 12(1), 9-27 (2016) doi: 10.17059/2016-1-1

12. Y. Vertakova, V. Plotnikov, ECONOMIC ANNALS-XXI, 166(7-8), 4-10 (2017) doi: 10.21003/ea.V166-01 